\title{
FASILITAS EDUKASI DAN HIBURAN BERBASIS TANAMAN DI DURI UTARA
}

\author{
Lieman $^{1)}$ \\ 1)Program Studi S1 Arsitektur, Fakultas Teknik, Universitas Tarumanagara, lieman1998@gmail.com
}

Masuk: 13-07-2020, revisi: 31-07-2020, diterima untuk diterbitkan: 24-09-2020

\begin{abstract}
Abstrak
Masyarakat kota memiliki tingkat stres yang tinggi. Rutinitas sehari-hari antara di rumah (first place) dan di tempat kerja (second place) merupakan faktor pemicu stres. Antara rumah sebagai first place dan tempat kerja atau sekolah sebagai second place ada celah untuk mengisi di antara dua hal tersebut. Maka hadirlah third place sebagai tempat pelarian antara first place dan second place. Ditempat itu sesorang akan datang untuk melepas stres dengan mengisinya dengan pembicaraan dan kegiatan. Sebuah arsitektur yang terbuka (open architecture) berusaha menghadirkan tempat ketiga (third place) di dalamnya. Hal itu mencoba menghadirkan sebuah wadah dengan beragam aktivitas yang dapat berganti sesuai perkebangannya. Wadah tersebut juga dapat digunakan oleh beragam usia dari anak-anak sampai dewasa. Proyek ini menggunakan pendekatan observasi dan studi literatur. Melihat langsung apa yang terjadi dilapangan. Kontekstualitas diterapkan dalam proyek untuk membuat bangunan yang selaras dan tampak sopan dengan sekitarnya. Proyek diangkat permasalahan yang ada di daerah perancangan. Dalam menghilangkan stres digunakan metode kegiatan yang menggunakan media alam. Media alam yang digunakan adalah tanaman. Menurut penelitian dengan melakukan kegiatan yang berhubungan dengan tanaman seperti menanam, merawat, atau memanen dapat mengurangi tingkat stres dalam jiwa. Kegiatan yang bersifat kreativitas yang dapat dinikmati oleh beragam kalangan usia, mulai dari anak-anak sampai dewasa. Interaksi yang lebih kreatif coba di terapkan dalam proyek fasilitas edukasi dan hiburan berbasis tanaman di Duri Utara.
\end{abstract}

\section{Kata kunci: stres; tanaman; tempat ketiga}

\begin{abstract}
Urban society has a high level stress. The daily routine beet home (first place) and at the workolace (second place) is a stress trigger. There is a gap to fill between first place and second place. So third place is a place for escape between first place and second place. At that place people will release the stress and fill it with conversation and activities. A open architecture try to present the third place in it. It try to bring place for various activities that can change according to development. That place can use for various age from child and adult. This project use observation approach and study of literature. See what happening on the field. Contextualities applied in this project, made building harmony and appear polite with surrounding. The project raised issue on the field. In release the stress used acitivies that use natural media methods. The natural media used is plant. According to research by doing activities related with plants such as planting, caring, or harvesting can reduce the level of stress in the soul. Creative activities that can be enjoyed by various ages, in childern to adult range. More creative interactions have been implemented in the project of plant-based educational and entertainment facilities in Duri Utara.
\end{abstract}

\section{Keywords: plant; stress; third place}




\section{PENDAHULUAN}

\section{Latar Belakang}

Menurut Inah (2013) Manusia merupakan makhluk sosial. Manusia membutuhkan interaksi antar individu. Rutinitas warga yang padat khusunya di daerah perkotaan, membuat kesempatan untuk berinteraksi dan melepas stres menjadi jarang. Tekanan di tempat kerja atau di sekolah membuat tingkat stres menjadi bertambah. Maka dari itu sebuah wadah diperlukan oleh masyarakat untuk menyalurkan stresnya.

DKI Jakarta yang merupakan sebuah Ibu Kota Negara dan pusat ekonomi bagi Indonesia dan daerah sekitarnya, berimbas kepada kepadatan dan mobilitas masyarakat yang tinggi. Kemacetan merupakan hal yang tidak terhindarkan di Jakarta saat jam sibuk. Maka mobilitas yang tinggi dan kemacetan membuang banyak waktu para warganya. Berdasarkan hal tersbut ada baiknya sebuah third place hadir di tempat yang dekat tempat masyarakat bekerja atau dekat dengan lingkungan tinggalnya. Pada proyek ini akan dirancang dekat dengan lingkungan hunian masyarakat.

Stres pada masyarakat dapat dihilangkan dengan disalurkan. Stres dapat dihilangkan dengan menggunakan media alam, salah satunya dalah media tanaman. Perasaan puas pada saat memanen, dan interaksi yang timbul dengan individu lainnya pada proses menanam membuat stres menjadi tersalurkan. Maka dibuatlah fasilitas edukasi dan hiburan berbsis tanaman untuk menjawab persoalan tersebut.

\section{Rumusan Permasalahan}

Manusia merupakan makhluk sosial, yang membutuhkan interaksi antar sesama. Untuk para penduduk kota besar yang sibuk dengan rutinitasnya. Masyarakat kota dewasa ini banyak yang tidak memiliki wadah untuk berinteraksi. Waktu dan jarak yang menjadi hambatan. Maka perlu dirancang sebuah wadah bagi masyarakat untuk berinteraksi dan menghilangkan stres. Perlu dicari juga lokasi dan tempat yang sesuai dengan proyek tersebut. Salah satu pergeseran yang terjadi di perkotaan adalah komersialisasi di segala bidang. Hal itu berdampak tersegmentasinya pengguna yang hadir di dalamnya. Perlu dipertimbangkan sebuat wadah yang di mana semua pengunjungnya adalah setara, dan segala golongan dapat hadir di dalamnya.

\section{Tujuan}

Penelitian bertujuan untuk mencari solusi wadah interaksi masyarakat. Mencari wadah yang sesuai dengan kebutuhan masyarakat. Sebuah program harus sesuai dengan apa yang masyarakat sekitar sukai. Membuat sebuah tempat ketiga yang dapat dipakai oleh semua orang. Mencari program yang dapat mengikat semua penggunanya. Sebuah proyek yang dirancang nantinya mengarah kepada proyek sosial bukan proyek yang terlalu komersial. Sisi komersial hanya ditujukan untuk keberlangsungan pengelola bangunan. Proyek yang nantinya hadir dapat menyatukan masyarakat sekitar.

\section{KAJIAN LITERATUR}

\section{Third place}

Third place merupakan sebuah ruang yang membentuk interaksi sosial masyarakat. Pada third place sesorang ingin menghilangkan stres dalam dirinya, rasa keterasingan dan kesepian. Pada third place manusia mencoba mengobati rasa bosan dari rutinitasnya. Pada third place individu mencoba lari dari first place-nya (tempat tinggal) dan second place (tempat kerja atau sekolah) (Oldenburg, 1999). 
Menurut Oldenburg (1999), ciri third place antara lain:

a. Neutral Ground

Alasan utama third place adalah Netral. Seseorang dapat mengunjungi dan pergi dari third place dengan bebas. Third Place merupakan tempat yang aman bagi segala pengunjungnya.

b. Leveler

Semua pengunjung third place harus setara. Semua kedudukan di tempat pertama dan ditempat kedua harus ditinggalkan. Semua orang akan diterima dengan tangan terbuka di tempat ini.

c. Conversation is Main Activity

Interaksi sosial yang dominan pada third place adalah percakapan. Para pengunjung akan saling bertukar informasi dan pikiran sebagai kegiatan utamanya.

d. Accessibility \& Accommodation

Tempat ketiga harus mudah diakses, dapat diakses kapan saja dan oleh siapa saja.

e. The regulars

Sesuatu yang membuat pengunjung ingin datang kembali ke third place adalah karena sesama pengunjung lainnya. Mereka datang karena ada kenalan.

f. Low profile

Karakteristik dari tempat ketiga harus seperti di rumah. Pengunjung harus merasakan seperti di rumah walaupun sedang jauh dari rumah. Kenyamanan pengunjung harus sangat dipehatikan. Bangunan juga harus kontekstual dengan lingkungan sekitar supaya tidak menjadi benda asing di Kawasan tersebut.

g. A mood is playful

Sebuah third place harus menjadi tempat yang menyenangkan untuk dikunjungi. Suasanan yang tercipta harus menyenangkan. Sesuatu yang terpenting adalah interaksi dan diskusi yang tercipta harus juga menyenangkan.

h. A home away from home

Sebuah perasaan seperti di rumah ketika berada di tempat ketiga ini. Perasaan yang dapat mengganbarkan seperti di rumah antara lain: Rootedness, merasa memiliki, dapat menenangkan batin, perasaan nyaman, dan hangat.

\section{Kreativitas}

Definisi kreativitas menurut KBBI adalah kemampuan mencipta atau daya cipta. Kreativitas merupakan sebuah kemampuan seseorang menciptakan sesuatu yang baru, baik berupa gagasan ataupun karya nyata. Sesuatu yang diciptakan tersebut berbeda dengan dengan yang pernah ada sebelumnya (Supriadi,2001). Kreativitas bisa juga didefinisikan sebagai kemampuan untuk mengkombinasikan sesuatu yang baru, berdasarkan apa yang telah ada sebelummnya, dapat berupa data, informasi, pengalaman atau pengetahuan (Munandar,1999)

Kreativitas memiliki 4 ciri-ciri, yaitu:

a. Kelancaran berpikir (fluency of thinking), kemampuan untuk memberikan jawaban atas penyelesaian masalah. Jawaban yang diberikan selalu lebih dari satu cara penyelesaian yang dicetuskan.

b. Keluwesan berpikir (flexibility), adalah kemampuan memberikan jawaban, ide, yang bermacam-macam atas sebuah permasalahan yang ada. Jawaban yang diberikan akan berasalh dari berbagai sudut pandang persoalan.

c. Elaborasi, adalah kemampuan untuk membuat suatu gagasan semakin kaya dan mendetail.

d. Originalitas, yaitu kemampuan memberikan jawaban yang unik atas sebuah permasalahan. Gagasan yang diberikan bisa tidak lazim. (Nur,2002)

Fasilitas Edukasi dan Hiburan Berbasis Tanaman 
Fasilitas merupakan hal-hal yang dibuat untuk mempermudah suatu aktivitas. Fasilitas dibuat untuk menunjang suatu kegiatan dapat berjalan dengan baik. Fasilitas dapat dalam fasilitas terdapat sarana dan prasarana penunjang kegiatan aktivitasnya. (Barnawi, 2013)

Fasilitas edukasi dan hiburan merupakan wadah yang dilengkapi dengan penunjang kegiatan berupa sarana dan prasarana untuk kegiatan edukassi dan hiburan. Jadi fasilitas edukasi dan hiburan berbasis tanaman merupakan wadah yang dilengkapi segala kebutuhan kegiatan edukasi dan hiburan yang berkaitan dengan tanaman.

\section{METODE}

Dalam mendesain proyek ini metode yang digunakan adalah metode kontektualisme dan pendekatan rasional. Menurut Jormakka, kontekstualisme adalah salah satu cara untuk merespon sebuah tapak. Dengan menggambar abreaksi dari berbagai morfologi kawasan sekitar dan mencoba merangkainya kembali menjadi komposisi baru dengan karakteristik yang mirip. Kontekstualitas dapat berlawanan dengan tipologi desain. Metode ini mengambil elemen-elemen bangunan yang istimewa dan tetap menghargai warna, proporsi, dan fenestasi. (Jormakka,2008).

Menurut Kari Jormakka, arsitektur membutuhkan adanya pengetahuan dasar dari berbagai ilmu di luar bidang arsitektur. Informasi yang dikumpulkan akan diolah dan diterapkan sebagai pertimbangan proses desain. Alternatif desain dapat dibuat dengan perkembangan informasi yang diterimanya. Metode ini disebut Rationalist Approaches (pendekatan rasiomal) (Jormakka,2008).

\section{DISKUSI DAN HASIL}

Lokasi tapak yang dipilih berada di kelurahan Duri Utara, Kecamatan Tambora, Kota Administrasi Jakarta Barat, Provinsi DKI Jakarta. Menurut Madina (2019) kecamatan Tambora merupakan kawasan kampung kota, yang digolongkan ke dalam kawasan padat dan kumuh.

Kelurahan Duri Utara memiliki tingkat kepadatan penduduk yang tinggi, bangunan yang padat, jalan lingkungan kecil berupa gang, dan minimnya ruang terbuka hijau (RTH). Hal tersebut mengakibatkan masyarakat merasakan kesesakan. Kesesakan yang terus-menerus mengakibatkan spatial crowding stress. Spatial crowding stress adalah stres karena kondisi spasial yang ada dilingkungan tersebut seperti jalanan yang sempit, kondisi bangunan yang berdempetan, dan keterbatasan ruang sebagai hal yang paling dominan membuat stres.

Kelurahan Duri membutuhkan sebuah wadah bagi masyarakatnya untuk mengurangi dampak dari kepadatan dan kurangnya ruang terbuka hijau (RTH). Wadah untuk menyalurkan stres warga. Sebuah fasilitas yang dapat dimanfaatkan oleh seluruh warga Duri Utara untuk melakukan relaksasi, mencari hiburan dan berkumpul untuk mengurangi stres.

\section{Ruang Terbuka Hijau di Kelurahan Duri Utara}

Kelurahan Duri Utara kekurangan lahan terbuka hijau. Berdasarkan data milik Pemerintah Provinsi DKI jakarta tahun 2018 mengenai ruang terbuka hijau, titik RTH di kelurahan Duri Utara hanya terdapat 2 buah. Pertama di jalan Cibubur seluas $1471 \mathrm{~m} 2$ dan di Jalan Duri Utara seluas $758 \mathrm{~m} 2$. Kedua jenis RTH tersebut memiliki jenis Jalur Hijau Jalan, yang berarti hanya memanfaatkan jalur hijau di sepanjang jalan. Dari data tersebut dapat disimpulkan bahwa jumlah RTH sangat sedikit jika dibandingkan luas kelurahan yang mencapai $0.41 \mathrm{KM} 2$. Persentase RTH pada kelurahan ini hanya $0.54 \%$ sangat jauh dibandingkan program pemerintah yang menetapkan $30 \% \mathrm{RTH}$. 
Maka dalam penerapan desainnya nanti akan dirancang ke arah penghijauan. Penghijauan baik secara Koefisien Dasar Hijau, atau berupa tanaman yang di tanaman pada bangunan. Hal ini untuk menyikapi lahan hijau yang terbatas.

\section{Kepadatan Penduduk}

Kecamatan Tambora merupakan salah satu kecamatan dengan keadatan penduduk tertinggi di Jakarta. Hal tersebut juga berlaku untuk kekurahan Duri Utara. Kondisi demografis penduduk Kelurahan Duri Utara dapat dikategorikan sangat padat. Kelurahan Duri Utara memiliki jumlah penduduk sebanyak 23.396 jiwa. Kelurahan ini memiliki luas wilayah sebesar $0.41 \mathrm{M} 2$. Kelurahan ini memiliki tingkat kepadatan sebanyak 57.017 jiwa/KM2. Jika mengacu kepada standar SNI 03-1733-2004 tingkat kepadatan tersebut dikategorikan sangat padat. Hal ini dapat terlihat dari kelurahan tersebut yang didominasi hunian dengan hunian deret dengan gang-gang kecil.

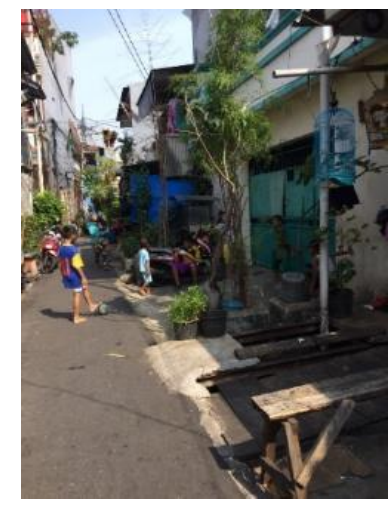

Gambar 1. Salah satu gang di Kelurahan Duri Utara

Sumber: Penulis, 2020

\section{Program}

Salah satu cara yang diambil untuk mengurangi perasaan stres adalah dengan melakukan kegiatan yang berhubungan dengan media alam. Salah satu media yang dapat dipakai adalah tanaman. Menurut penelitian melakukan kegiatan yang berhubungan dengan tanaman dapat menguranngi stres (Sari et al., 2014)

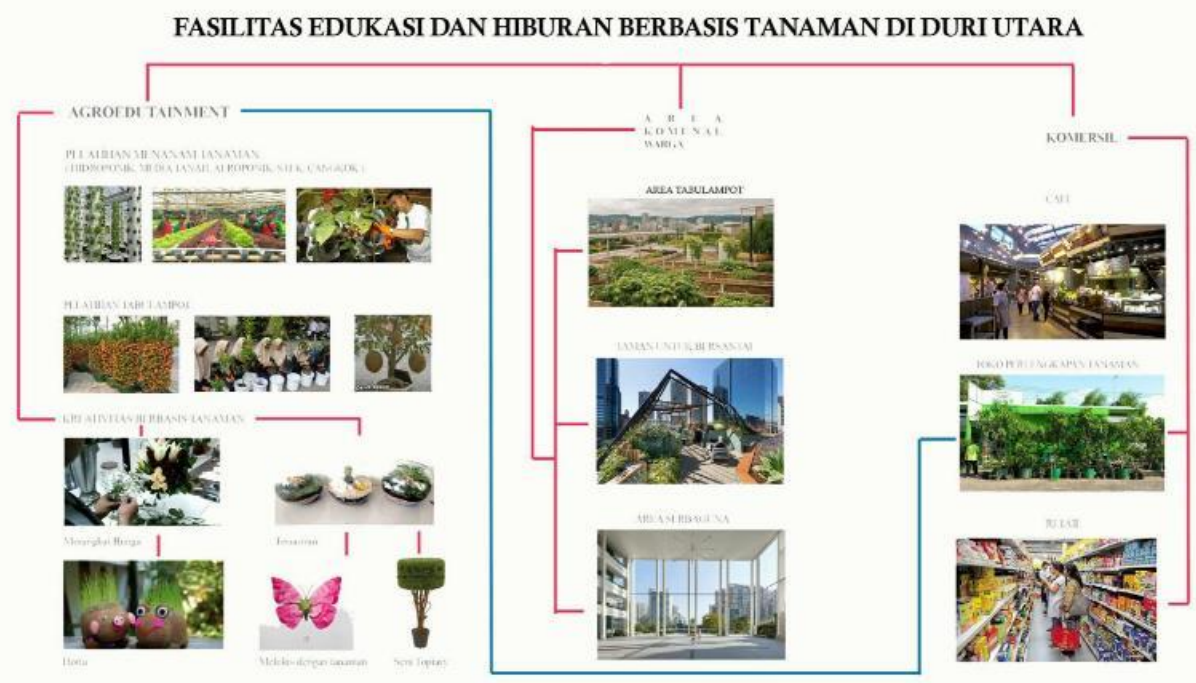

Gambar 2. Diagram program fasilitas edukasi dan hiburan berbasis tanaman di Duri Utara Sumber: Penulis, 2020 
Berdasarkan hasil kajian dan melihat kondisi tapak, program yang dibuat adalah fasilitas edukasi dan hiburan berbasis tanaman di Duri Utara. Secara garis besar program ini terlihat pada diagram di atas. Program utama pada proyek ini adalah agroedutainment, ruang komunal warga dan area retail.

Program Agroedutainment merupakan program utama pada proyek ini. Agroedutainment merupakan edukasi hiburan berbasis tanaman. Di dalam program kegiatan yang diberikan adalah pelatihan tanaman (Tabulampot) dan kreativitas berbasis tanaman (Horta, merangkai bunga, melukis dengan tanaman, Terrarium, jar decoupage, dan seni topiary). Program ini ada yang berada di dalam ruangan dan juga di luar ruangan. Program kreativitas yang dipilih dapat dinikmati oleh beragam rentang usia, mulai dari anak-anak sampai dewasa.

Program area komunal merupakan program yang dapat dinikmati oleh seluruh warga tanpa ikatan. Program ini terdiri dari area taman tabulampot, area taman untuk bersantai, dan ruang serbaguna. Program ini dapat dipakai warga untuk sekedar bersantai sambil duduk dan bercengkrama dengan warga lainnya. Pada area komunal terdapat area yang dapat dipakai untuk beragam kegiatan, seperti untuk latihan menari, kegiatan senam, lomba, atau kegiatan pemilu.

Program retail merupakan program untuk menghasilkan uang demi keberlanjutan operasional fasilitas ini. Program ini terdiri dari Café, food court, retail sewa (minimarket), dan toko tanaman. Food court akan berupa kios-kios untuk berdagang makanan. Café akan diisi oleh kedai-kedai kopi kekinian, penyewa akan berupa kios-kios yang dapat disewa. Retai sewa akan berupa mini market modern. Toko tanaman dibuat sebagai tempat untuk menjual bibit tanaman, mensuplai kebutuhan peralatan dan pelengkapan kegiatan yang berhubungan dengan proyek ini.

Fasilitas Edukasi dan Hiburan Berbasis Tanaman di Duri Utara, jika dibandinkandengan ciri third place menurut Oldenburg, yaitu:

a. Neutral Ground

Fasilitas Edukasi dan Hiburan Berbasis Tanaman di Duri Utara dapat dikunjungi oleh semua orang, karena program yang diusung bersifat umum dan dapat dimanfaatkan oleh siapa saja.

b. Leveler

Semua pengunjung Fasilitas Edukasi dan Hiburan Berbasis Tanaman di Duri Utara adalah setara. Pada fasilitas ini semua pengunjung dapat berbaur.

c. Conversation is Main Activity

Program pada Fasilitas Edukasi dan Hiburan Berbasis Tanaman di Duri Utara dapat mengundang untuk munculnya percakapan dan diskusi. Fungsi taman dan café dapat dimanfaatkan sebagai area berbincang yang umum. Jika pada fasilitas edukasi tanaman dan perpustakaan pembicaraan akan lebih berfokus kepada hal tanaman dan kreativitas.

d. Accessibility \& Accommodation

Bangunan Fasilitas Edukasi dan Hiburan Berbasis Tanaman di Duri Utara memiliki akses pada area taman, secara terbuka 24 jam dalam satu minggu. Akses menuju ke taman tidak perlu melalui area lain yang lebih tertutup.

e. The regulars

Fasilitas ini membuat para pengunjung ingin datang kembali karena ingin bertemu kembali dengan kenalan.

f. Low profile

Bangunan Fasilitas Edukasi dan Hiburan Berbasis Tanaman di Duri Utara dibuat kontekstual supaya membuat kesan bangunan yang ramah dan nyaman seperti di rumah. 


\section{g. A mood is playful}

Fasilitas Edukasi dan Hiburan Berbasis Tanaman di Duri Utara memiliki program yang menyenangkan tetapi memiliki sisi edukasi. Hal tersebut membuat pengunjung merasa senang saat berada di tempat ini.

h. A home away from home

Fasilitas Edukasi dan Hiburan Berbasis Tanaman di Duri Utara memiliki tempat untuk bersantai dan berkumpul. Pengunjung akan merasa nyaman dan hangat karena dikelilingi oleh orang yang memiliki kesamaan.

\section{Lokasi Tapak}

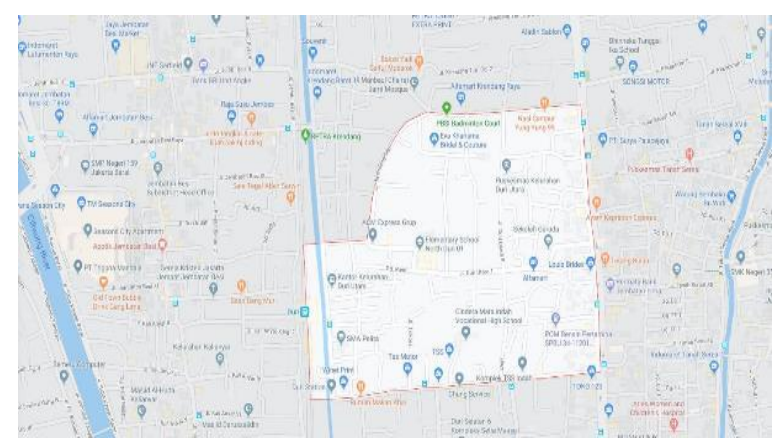

Gambar 3. Peta Kelurahan Duri Utara

Sumber: Google Maps 2020

Lokasi tapak pada proyek ini berada di Kelurahan Duri Utara. Tapak yang pilih berada di jl. Duri Utara, Kelurahan Duri Utara, Kecamatan Tambora, Kota Administrasi Jakarta Barat, Provinsi DKI Jakarta. Kelurahan Duri Utara merupakan salah satu dari 11 kelurahan di kecamatan Tambora. Kecamatan Tambora merupakan kecamatan padat penduduk di DKI Jakarta. Di Seberang tapak terdapat sebuah sungai yang bernama Kali Krendang. Kali Krendang membatasi kelurahan Duri Utara dengan kelurahan Kali Anyar di sebelah baratnya.
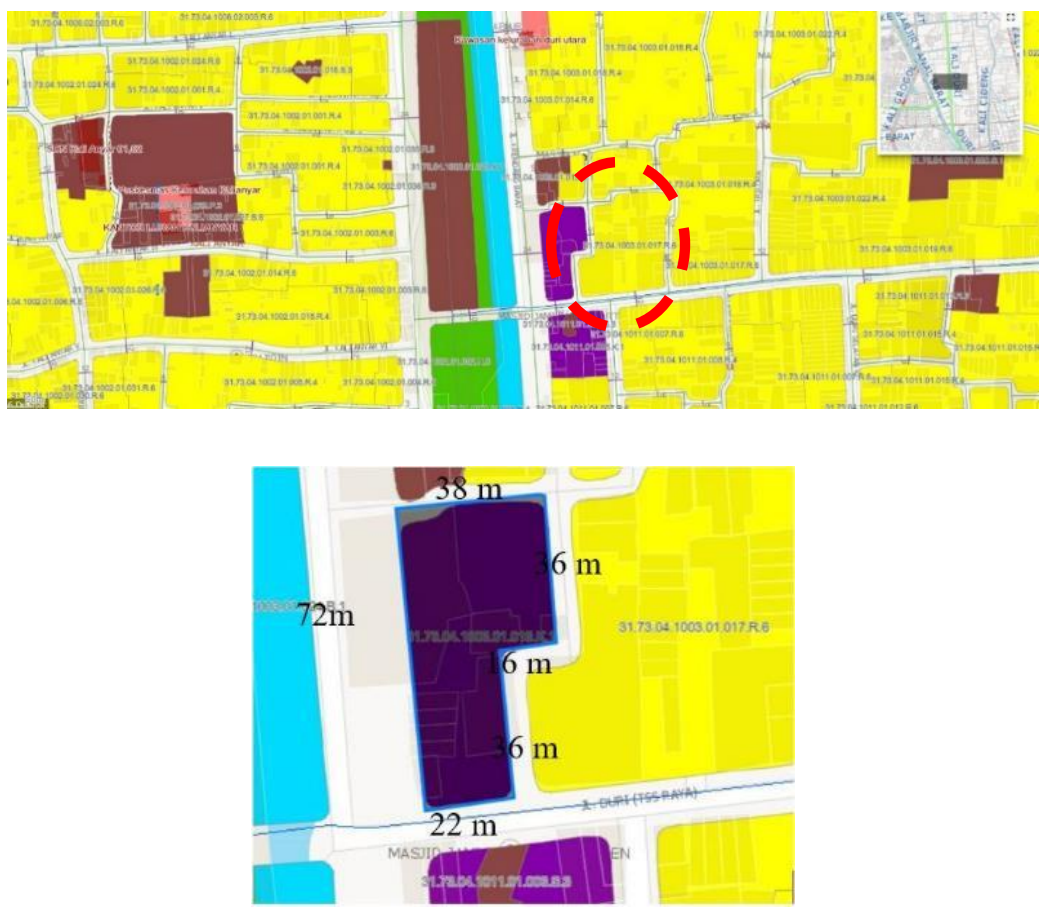

Gambar 4. Peta Zonasi Kelurahan Duri Utara Sumber: Peta Tata Ruang DKI Jakarta (RDTR) 
Lokasi tapak berada di kawasan pada penduduk Kecamatan Tambora, Jakarta Barat. Kawasan sekitar tapak merupakan kawasan padat penduduk. Di sekitar tapak di dominasi oleh zona kuning, zona permukiman penduduk.

Zonasi tapak merupakan zona ungu yaitu zona perkantoran. Bangunan yang diizinkan adalah perkantoran, perdagangan dan jasa.

\section{Analisis Kawasan}

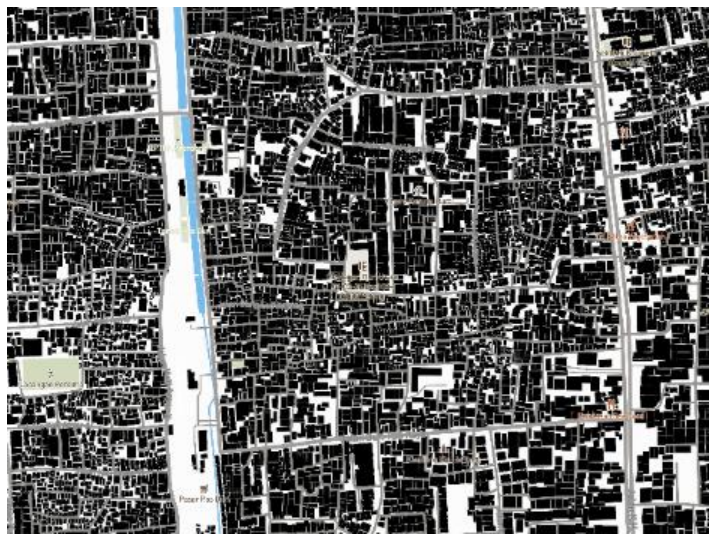

Gambar 5. Urban Fabric Kelurahan Duri Utara Sumber: Mapbox 2020

Pada gambar Urban-fabric kawasan Duri Utara dapat dilihat bahwa kawasan ini bertipe organik. Kawasan berkembang tanpa terencana. Kawasan ini sangat padat penduduk dengan jalan lingkungan berupa gang-gang kecil, dengan hunian yang bertipe deret/dempet. Kawasan ini juga sangat minim ruang terbuka hijaunya.

\section{Gubahan Massa}

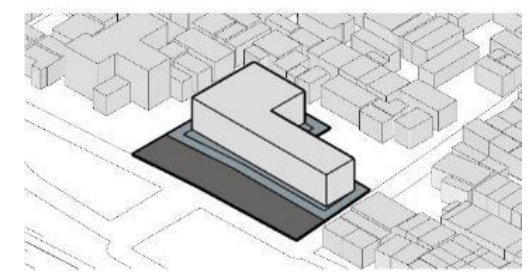

Gambar 6. Gubahan Massa tahap 1 Sumber: Penulis, 2020

Bentukan awal gubahan massa mengikuti bentuk massa, yaitu leter L. Bentuk tersebut diambil untuk memaksimalkan lahan yang ada. Bentuk awal tersebut dimaksudkan untuk mengikuti urban fabric kawasan

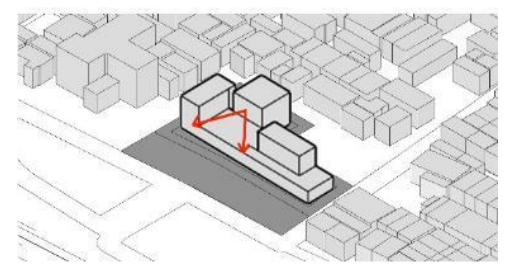

Gambar 7. Gubahan Massa tahap 2 Sumber: Penulis, 2020 
Massa pada lantai 2 dibuat terpencar untuk mengurangi kesan padat dan bulky pada bangunan. Susunan massa lantai 2 juga dibuat terpusat ke tengah lantai 2. Pada lantai 2 juga akan diberikan roof garden untuk memberikan kesan hijau pada bangunan.

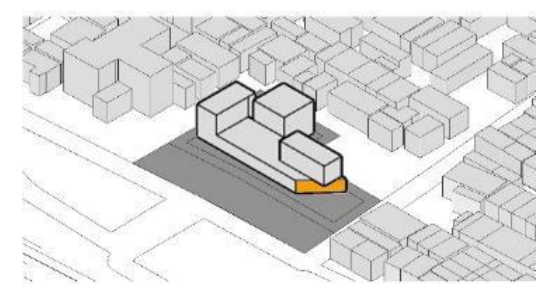

Gambar 8. Gubahan Massa tahap 3 Sumber: Penulis, 2020

Massa bangunan yang menghadap hoek dibuat miring untuk menghargai hoeknya. Sisi tersebut juga dimaksud sebagai point of interest bangunan.

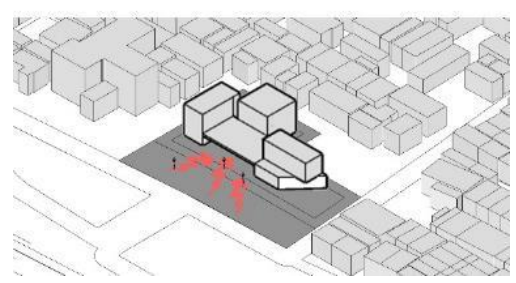

Gambar 9. Gubahan Massa tahap 4 Sumber: Penulis, 2020

Lantai 1 bangunan dibuat pilotis. Hal tersebut bertujuan untuk memberikan kesan mengundang dan terbuka. Hal tersebut dimaksud juga untuk memberi tahu akses utama bangunan. Bangunan yang pilotis dapat digunakan sebagai area komunal bagi warga untuk mengadakan kegiatan.

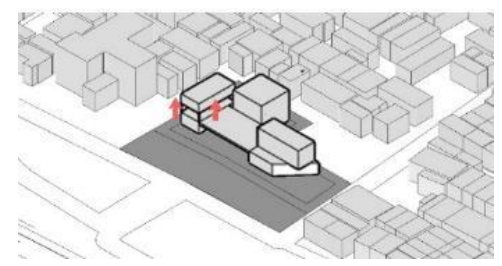

Gambar 10. Gubahan Massa tahap 5

Sumber: Penulis, 2020

Lantai 2 bangunan diangkat. Hal tersebut dimaksudkan untuk memberikan kesan terbuka dan menyatu dengan taman di lantai 2.

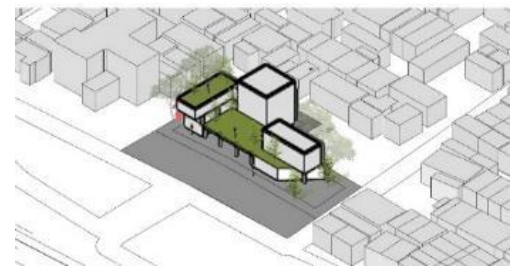

Gambar 11. Gubahan Massa tahap 6 Sumber: Penulis, 2020 
Bangunan di lantai 2 dan lantai 3 dibuat roof garden. Hal tersebut bertujuan untuk memberikan kesan hijau pada bangunan. Roof garden pada bangunan juga dapat digunakan pengunjung untuk melakukan kegiatan atau hanya sekedar bersantai dan duduk-duduk.

\section{Zoning Bangunan}

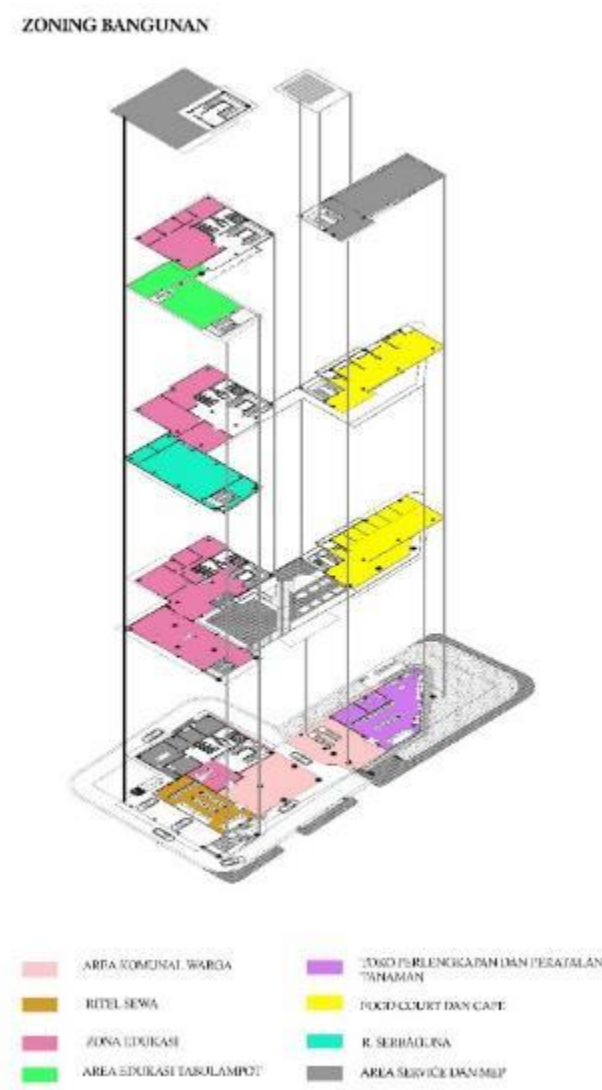

Gambar 12. Zoning Bangunan

Sumber: Penulis, 2020

Pada lantai 1 bangunan, terdapat retail sewa, area komunal warga, toko perlengkapan dan peralatan tanaman, dan area service. Area retail sewa ditempatkan di lantai 1 untuk memberikan aksesibilitas yang mudah bagi pengunjung yang ingin berbelanja. Area komunal warga ditempatkan pada lantai 1 supaya pengunjung dapat menikmatinya tanpa menggangu aktivitas pada area lainnya. Toko perlengkapan dan tanaman berfungsi sebagai penyedia peralatan dan penglengkapan kegiatan di bangunan ini.

Pada lantai 2 terdapat dua 3 zona. Pertama zona edukasi, yang terdiri dari area edukasi topiary, gallery seni, dan kantor pengelola fasilitas. Kedua zona roof garden. Area ini dapat dimanfaatkan pengunjung untuk bersantai, kegiatan senam, area display topiary, dan area makan outdoor. Ketiga area food court.

Pada lantai 3 bangunan dapat dibagi menjadi 3 zona. Pertama zona edukasi berupa kelas pelatihan kreativitas tanaman (kelas horta, melukis dengan tanaman, jar decoupage, terrarium, potty, merangkai bunga). Kedua yaitu ruang serbaguna/audio-visual/seminar. Ketiga Café. Pada lantai 4 terdapat 3 zona. Pertama yaitu zona edukasi berupa perpustakaan. Kedua roof garden. Area ini digunakan untuk area edukasi pelatihan tanaman tabulampot (tanam buah dalam pot), serta dapat juga digunakan untuk area bersantai. Ketiga yaitu area perawatan tanaman. 


\section{Desain}
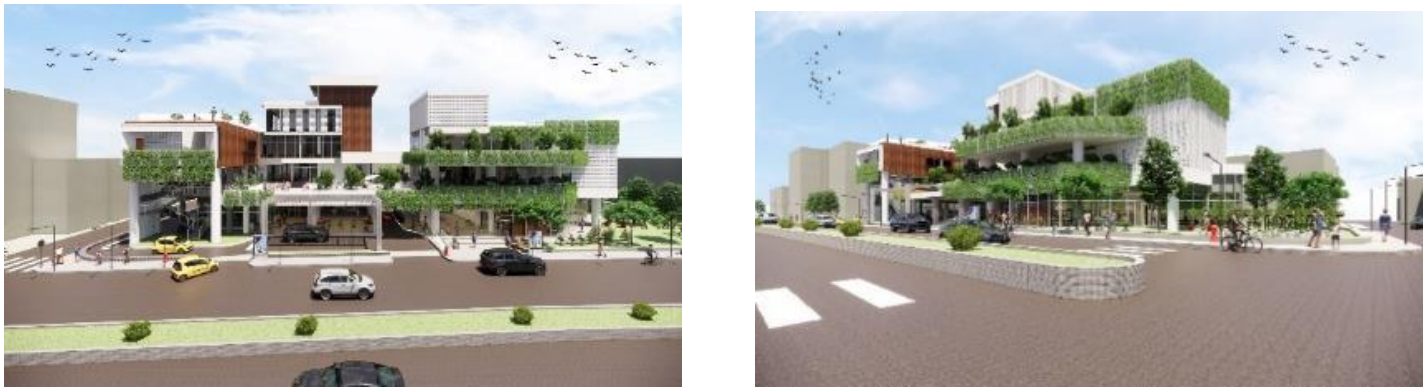

Gambar 13. Perspektif Eksterior Bangunan

Sumber: Penulis, 2020

Façade bangunan didesain tidak memiliki banyak ornamen. Warna yang digunakan adalah warna-warna netral. Tekstur pada façade yang utama menggunakan motif dari roster dan kayu. Material tersebut memberikan kesan netral dan natural pada bangunan. Ditambah dengan penggunaan tanaman sulur pada façade bangunan memberikan kesan hijau yang lebih banyak

\section{KESIMPULAN DAN SARAN}

\section{Kesimpulan}

Kepadatan bangunan tempat tinggal dan kurangnya ruang tebuka hijau mengakibatkan stres bagi masyarakat. Salah satu cara mengurangi stres adalah berinteraksi dengan media tanaman. Pada proyek Fasilitas Edukasi dan Hiburan Berbasis Tanaman di Duri Utara, mencoba menghadirkan third place bagi masyarakat Duri Utara. Masyarakat dapat berkegiatan, bercengkrama dengan sesama, dan menghilangkan stres di bangunan ini. Bangunan ini menjadi wadah bagi masyarakat berkumpul, berinteraksi, dan melatih kreativitas. Dengan kegiatan kreativitas berbasis tanaman semua golongan usia dan latar belakang dapat menikmati kegiatan di proyek ini.

\section{Saran}

Pada proyek ini penulis memiliki beberapa saran untuk desain kedepannya, antara lain:

a. Aspek hijau pada bangunan dapat diperbanyak pada proyek berikutnya. Aspek hijau berupa tampilan façade-nya, pada taman, interior-nya, dan programnya.

b. Program komersilnya dapat dikurangi presentasenya terhadap keseluruhan luas bangunan.

\section{REFERENSI}

Adji, P. (2013). Pengaruh Retail Mix Terhadap Keputusan Pembelian Mahasiswa UK Petra Di Circle K Siwalankerto Surabaya. Jurnal Strategi Pemasaran. 1(2):1-10

Barnawi, dan Arifin, M. (2011). Manajemen Sarana dan Prasarana Sekolah.Yogyakarta: Ar-Ruzz Media.

Inah, E. N. (2013). Peranan komunikasi dalam pendidikan. Al-Ta'dib

Jormakka, Kari; Schurer, Oliver; Kuhlmann, Dorte. (2008.). Design methods / Kari Jormakka with Oliver Schurer and Dorte Kuhlmann. Basel : Birkhauser,.

Madina, R. F., Lahji, K., Tundono, S., \& Fahrani, A. (2019). Pencegahan kebakaran pada lingkungan permukiman padat di kelurahan krendang, kecamatan tambora, jakarta barat. Jurnal Abdi Masyarakat Indonesia, 1(3).

Munandar, S.C.U. (1999). Mengembangkan Bakat dan Kreativitas Anak Sekolah. Jakarta: PT. Gramedia Widiasarana Indonesia.

Nur, S. (2002). Membangun Pribadi Kreatif. Bandung: Rineka Cipta 
Oldenburgh, R. (1989). The Great Good Place. US: Da Capo Press

Sari, A. P., Yusuf, A., \& Wahyuni, E. D. (2014). Perubahan Tekanan Darah Pada Lansia Dengan Hipertensi Melalui Therapeutical Gardening di UPT PSLU Magetan. Critical Medical and Surgical Nursing Journal, 3(1), 1-10.

Supriadi, D. (2001). Kreativitas, Kebudayaan, dan Perkembangan Iptek. Bandung: ALFABETA 